Relations industrielles

Industrial Relations

\title{
Practical Professional Application
}

\section{The Apprenticeship Commission in the Shoe Industry}

\section{Léonce Girard}

Volume 5, numéro 8, mai 1950

URI : https://id.erudit.org/iderudit/1023384ar

DOI : https://doi.org/10.7202/1023384ar

Aller au sommaire du numéro

Éditeur(s)

Département des relations industrielles de l’Université Laval

ISSN

0034-379X (imprimé)

1703-8138 (numérique)

Découvrir la revue

Citer cet article

Girard, L. (1950). Practical Professional Application: The Apprenticeship

Commission in the Shoe Industry. Relations industrielles / Industrial Relations,

5(8), 73-74. https://doi.org/10.7202/1023384ar

Tous droits réservés @ C Département des relations industrielles de l’Université Laval, 1950
Ce document est protégé par la loi sur le droit d'auteur. L'utilisation des services d'Érudit (y compris la reproduction) est assujettie à sa politique d'utilisation que vous pouvez consulter en ligne.

https://apropos.erudit.org/fr/usagers/politique-dutilisation/ 
Thus a pension appears as a supplement to wages which the employer, according to sound social philosophy, is bound to set aside for his employees to enable them to save up for their old age, and which the employees, on the other hand, have the right to lay claim to.
Thus a pension is part of the remuneration of the worker, and the share which the employer is obliged to set aside is properly a part of the employee's wages. So if an employer refuses to set up a pension fund, it is the same as though he refused to grant a wage increase.

\title{
PRACTICAL PROFESSIONAL APPLICATIONS
}

\author{
The Apprenticeship Commission in the Shoe Industry
}

LÉonce Girard

If you ever happened to interest yourself in an apprenticeship commission, you were probably asked this customary question: "What business have apprenticeship commissions in industry or education ?' In general, the answer is quite simple: they wish to promulgate professional guidance by stressing the industrial point of view.

\section{General view}

However, in order to answer the question more explicitly, I shall cite as an example the Apprenticeship Commission of the shoe industry with which I am acquainted. I shall attempt to elucidate the means employed to promote instruction by constant adaptation to the contemporary needs of the industry.

With this end in view, the Commission first drew up a balance sheet of the man-power of the industry according to carefully assembled statistics; next, it fixed precisely the number of its apprentices and journeymen in such fashion as not to overcrowd the industry but at the same time to furnish it qualified recruits in sufficient number.

Secondly, the Commission insisted that the schools provide instruction in the function of machines employed in present-day industry and recommended that all outmoded or useless equipment be discarded. The Commission likewise drew up a list of important operations to be taught so that the student might become a qualified worker and not merely an unskilled labourer or even a specialist.

The Apprenticeship Commission also insisted on choosing itself the technical instructors and suggested to the school authorities those who seemed to be the most capable of teaching the trade as it is practiced today. It kept the authorities and faculty abreast of new procedures and technical developments so that the school might be up to date in its manner of instruction, and recommended that all instruction relating to outdated procedures be abandoned. The Commission held that the theoretical courses (language, mathematics, drawing, physics, hygiene, anatomy) be taught not in a purely theoretical manner, but with reference to industrial needs.

With the aid of the Ministry of Labour and of the Ministry of Youth, it founded two schools of footgear, one at Montreal and one at Quebec, where it provided day and night courses. It organized factory courses throughout the Province for those employees who were unable to go to the schools; finally, it published information for all those who could not be reached by the courses.

Worthy of mention is the fact that the Apprenticeship Commission arranged that those who acquired a certain degree of skill in the day-time courses at school obtain and keep a stable position in the industry. This service benefits especially daytime students, since the great majority of apprentices who follow improvement courses during the evening, either at school or in the factory, are already employed in the industry.

In general, that constitutes the position of the Apprenticeship Commission of the shoe industry. There are other apprenticeship commissions with different manners of functioning according to the needs of their respective industries; these, too, have accomplished equally satisfying results. 


\section{A Few of the Results}

But, before making a detailed study of the methods and procedures employed by the Apprenticeship Commission of the shoe industry, a preliminary question arises: has this Apprenticeship Commission, after four years of existence, accomplished any appreciable results, worthy of being brought to public attention?

Let us examine the facts. Two or three years ago, a group of young people from fifteen to twenty years of age was pennyless, without vocation and unemployed. Today, after having studied under the auspices of the Apprenticeship Commission of the shoe industry, they have become key men in this industry: managers, assistant managers, qualified workers in important factories. It must be admitted that it is well worth the trouble of seeking out the causes of such results.

In the last three years, thirty-one students have completed their daytime courses at the Montreal school. The Apprenticeship Commission maintains contact with twenty-nine of them. These twenty-nine apprentices have become the following today: one is a manager, two are assistant managers, one is a foreman, four are assistant foremen, one is a pattern maker, two are stylists, three are salesmen, four are qualified workers, three are key men in overseeing the general manufacture of the product, four are specialised workers, one is a shoemaker on his own account, one is a shoemaker for the army, one is a university student, and one is a religious.

\section{The Employment Service}

Professional training is supposed to prepare wage earners for paying jobs in industry and commerce. If the student cannot find a steady job after completing his training period, he might as well not have taken the course. Why train an employee in special skills if they cannot be put into use afterwards ?

Hence it is not surprising that the apprenticeship commission has accorded special attention to the employment of students who have reached a certain degree of competence.
For this purpose, the apprenticeship commission carefully notes the qualifications of the apprentices in order to make an exact recommendation of them to the manufacturers. When needed, a letter is addressed to all the firms of the region, giving the names of the students who have completed their course in school and indicating the important operations they are able to perform, at least in the capacity of apprentices.

The apprenticeship commission has also charged itself to appeal to the Christian sentiments and social spirit of employers; it has asked numbers of employers to consider apprentices coming out of school, not as strangers, but as their own children, and to set themselves the task of discovering their qualities with the same benevolence as if they were their own sons or daughters. Industrial leaders know it is preferable to receive into their service a new employee just coming from school with a Christian social training than some unknown one whose convictions and principles may not be commendable.

Finally, the apprenticeship commission has asked manufacturers to give it advance notice before discharging a student from their employ. This demand was agreed to by all. The commission never asks an employer to keep a student, no matter what the reason, but only to advise it in the event it would wish to send him where there would be possibility of another job. And why? So the student will not be discouraged, so he will not lose the love of his trade and his enthusiasm to learn and progress.

At the present moment, as we have seen above, the former students working now in industry have steady jobs.

An important fact to note. There were periods of seasonal unemployment in December, 1948 and January 1949, and again in December 1949 and January 1950. However, not one of the students of the school was laid off during these periods. This is a sign that, in spite of the deficiences proper to their age, they are qualified workers. How did the apprenticeship commission succeed in turning raw recruits into qualified workmen ? This will be described in the next installment. 